\title{
Dolomitic plasters in Indian monuments and its characterization
}

\begin{abstract}
Carboniferous lime stone is commonly used in India's most of ancient monuments with beautiful plasterworks. However, analytical data indicate use of dolomitic lime in some of our monuments making it prone to damage by wetting and need special care. On the basis of mineralogical/chemical composition data, it is observed that dolomitic lime were used in the plasterworks of group of monuments at Alampur (6-7 ${ }^{\text {th }}$ AD) constructed by Chalukya's of Badami with higher addition of hydraulic component to give strength \& durability to the plasters. Studies also indicate that lime used in the preparation of plaster of Lotus Mahal, Hampi WHS (1336-1570 AD) may not always be of same origin as at some places slightly dolomitic lime source quite different to other has been used in the course of construction. The ratio of binder to inert also indicates the provenance of materials used in the construction of Hampi plasters works are not always the same. The data also provide a better understanding about the nature of mortars used in different period for technological evaluation as well as for the benefit of conservators for re-plastering works.
\end{abstract}

Keywords: Calcite, dolomite, hydraulic, ancient plasters, carboniferous
Volume I Issue 6 - 2017

MR Singh
National Museum Institute of History of Art, India

Correspondence: MR Singh, National Museum Institute of History of Art, India, Tel +9l-9890623704, Email m_singh_asi@yahoo.com

Received: September 21, 2017 | Published: October 05, 2017

\section{Introduction}

During exploration of past, the archaeologists often come across many objects carved with beautiful plasterworks. Based on the design, shape, area of excavation and physical parameters archaeologists date the plasters to a period. However, chemical characterization of these materials is highly informative to investigate the techniques \& type of raw materials used for proper correlation of dates with the archaeological findings and to understand nature of plasters.

India has many monuments designed and carved with beautiful plasterworks. These plasters, mostly made from locally available materials have stood destructive action of the nature to a large extent with a few exceptions because it's unique characteristics. The conservation of these plasters for posterity and scientific methodology to understand method \& technique of preparation of these simple materials are attracting archaeologists and archaeological conservators all over the world. Although the plasters of other important cultures of the world have been well investigated, very little work have been done on ancient Indian plasters on which very few published data are available. ${ }^{1-4}$

Studies indicate that mortars have been prepared using any available materials at construction site. The lime stone (Carboniferous, dolomite or perhaps even chalk ) is said to have been burnt in pits, slaked with water and stored for at least a month or perhaps as much as a year. ${ }^{5}$ For building industry, lime was mixed with sand and organic matters in preparation of plasters although at few places pure lime has also been used ${ }^{6}$ in ancient period. Though cement, a modern building material which is prepared with very modern and complicated technology shows distress and cracking in its life span of 60-80 years, the ancient plasters are still in good state since hundreds of years as no life span has been attributed to the plasters provided it is saved from seepages of water, bacterial \& insect activity or any short of physical damage. It is interesting to study this wonderful building material which is prepared with very simple technology but have many characteristic features superior to that of cement. Houses made of lime mortar keep it warm in winter and cold in summer. Lime mortars also absorb little movement of ancient building and absorb shock waves at the cost of saving main structure. The mortars also act as cushion between the bricks/stones absorbing static friction and seismic shocks and give durability and elasticity to ancient structures. In coastal regions, it works as sacrificial layer to save the ancient stone works from the action of saline atmosphere. ${ }^{7}$ A new trend of constructing modern houses with lime works are slowly coming into practice in western world.

Due to variation in the composition of raw materials used at different places, the plaster and technique of its preparation vary from each other. It is very specialized area where availability of raw materials in $\&$ around has a strong bearing on the methods of preparation. ${ }^{8}$ Though the major components of plasters of all ages are lime \& silica, there exists a definite variation in the composition due to addition of other strengthening materials. Soft \& gritty sand free from organic matters and sea salts has invariably been added to the plaster to give body and uniform shrinkage. The addition of sand to the lime increased slowly as there are some ancient plasters that have been detected as pure lime. The proportion of sand used as filler to the lime used as binder differ in the plasters of different period and this has a direct impact on the durability and strength of the plasters. Previously, very little sand was found to be added with the lime. However, with the passage of time more sand was added since in modern time we maintain lime/silica ratio of 1:3 for best quality plaster. Thus, the lime/ silica ratio of the plasters varies in different archaeological periods indicating the state of technology available in those periods as well as durability of such plasters. Results indicate that though our ancestors were familiar with the properties of sand, but unfortunately were not sure about the optimum concentration of sand in which it should be mixed to get maximum strength and hence we find variations in the lime plasters of different period. The minimum use of sand to the lime in ancient plasterworks may be due to:

A. Procurement of such a high quality of sand and reduction of its grain size wherein its can be easily mixed with the lime 
B. No proper knowledge of properties of sand as well as its optimum level required for the good quality plaster

C. Availability of adequate quantity of organic materials easily having good binding properties.

Another important constituent of plaster is the addition of organic materials, a feature still in use. ${ }^{9}$ The different organic materials which were opted for use in the ancient time are rice husk, jute fibres, gum, glue, Jaggery and extract of many plants etc. These organic materials not only diminish the chances of cracking of plasters but also increase its overall binding capacity. It is difficult to determine exact nature of organic materials since it has altered much during the course of time. Moreover, the overall concentrations of organic additives vary not only in different archaeological period but also at different locations of the same monument. The types of organic materials used depend on its availability in that particular zone. Whereas in India, the plasters of Hampi, Bidar Fort, Alampur were found to contain Jute fibres, the Ajanta Cave plaster contain rice husk, plant fibres \& seeds. ${ }^{10} \mathrm{Gum}$, Glue, Egg white etc., seem to have been added in the plasterworks of Charminar, Golconda Fort. These variations coupled with difference in chemical nature of raw material have added complexity to the plaster during scientific investigation.

It is also essential to investigate whether any plaster has been prepared from dolomite or limestone which contains no or very little magnesium. It has been observed that dolomitic plasters are liable for greater damage if it gets wet as compared to plasters of similar composition without or negligible amount of magnesium compounds. ${ }^{11}$

Several methods of chemical analysis have been proposed for the characterization of ancient mortars. ${ }^{12}$ The result of such analysis is expressed in the form of mineralogical composition as well as in the standardized oxide form. In the present study, lime plasters of different archaeological monuments pertaining to various historical period have been analysed and minima of lime/silica ratio have been correlated to understand its nature. The studies are also important for thorough understanding about the nature of plasters employed in different period. For re-plastering of damaged plaster, the conservators are required to be aware about the optimum concentration of constituents required for the preparation of plaster, reduction of grain size, optimum use of organic materials or the actual methods of preparation

Table I Percentage composition of Lime Plasters of different period

\begin{tabular}{|c|c|c|c|c|c|c|c|c|c|c|c|}
\hline Sr. no & $\mathrm{SiO}_{2}$ & $\mathrm{Fe}_{2} \mathrm{O}_{3}$ & $\mathrm{Al}_{2} \mathrm{O}_{3}$ & $\mathrm{TiO}_{2}$ & $\mathrm{CaO}$ & MgO & $\mathrm{Na}_{2} \mathrm{O}$ & $\mathbf{K}_{2} \mathbf{O}$ & MnO & LOI & $\mathrm{CaO} / \mathrm{SiO}_{2}$ \\
\hline I & 5.5 & 1.27 & 1.82 & 0.12 & 47.65 & 1.21 & 1.65 & 0.54 & 0.04 & 37.1 & 8.67 \\
\hline 2 & 22.29 & 1.39 & 4.19 & 0.14 & 38.4 & 0.65 & 0.2 & 1.5 & 0.03 & 29 & $\mid .51$ \\
\hline 3 & 41.8 & 2.73 & 5.96 & 0.47 & 24 & 0.75 & 0.21 & 2.35 & 0.05 & 18.5 & 0.57 \\
\hline 4 & 35.12 & 1.92 & 5.36 & 0.19 & 26.58 & 0.78 & 1.12 & 1.98 & 0.05 & 21.1 & 0.75 \\
\hline
\end{tabular}

Golconda Fort (I5I8-I687 AD)

\begin{tabular}{|c|c|c|c|c|c|c|c|c|c|c|c|}
\hline Sr. no & $\mathrm{SiO}_{2}$ & $\mathrm{Fe}_{2} \mathrm{O}_{3}$ & $\mathrm{Al}_{2} \mathrm{O}_{3}$ & $\mathrm{TiO}_{2}$ & $\mathrm{CaO}$ & $\mathrm{MgO}$ & $\mathrm{Na}_{2} \mathrm{O}$ & $\mathbf{K}_{2} \mathbf{O}$ & MnO & LOI & $\mathrm{CaO} / \mathrm{SiO}_{2}$ \\
\hline 1 & 41.8 & 5.96 & 1.73 & 0.11 & 24 & 0.75 & 1.04 & 2.35 & 0.05 & 19.5 & 0.57 \\
\hline 2 & 46.47 & 5.35 & 1.56 & 0.15 & 23.38 & 1.2 & 0.5 & 1.15 & 0.03 & 19.5 & 0.5 \\
\hline 3 & 44.75 & 3.68 & 1.82 & 0.19 & 24.72 & 1.12 & 0.86 & 1.25 & 0.04 & 20.8 & 0.55 \\
\hline 4 & 38.4 & 2.76 & 0.67 & 0.07 & 28.86 & 0.53 & 0.96 & 0.65 & 0.02 & 22.1 & 0.75 \\
\hline 5 & 46.28 & 4.36 & 1.66 & 0.24 & 23.06 & 1.46 & 0.71 & 2.52 & 0.03 & 18.9 & 0.5 \\
\hline 6 & 49.47 & 1.66 & 6.35 & 0.15 & 21.96 & 1.19 & - & - & - & 18.8 & 0.44 \\
\hline
\end{tabular}

Charminar (I59|-I593AD)

of plaster. This will ensure continuity of plaster having similar aging characteristics for re-plastering works.

\section{Results \& discussion}

As no samples of plasters were available in respect of Post Ashokan (200 B C), Satavahana (200 AD), Ikshvaku (300 AD) data were collected from elsewhere. ${ }^{12}$ Plaster samples of Alampur, Hampi, Bidar, Charminar, Golconda Fort etc were analysed by methods described earlier ${ }^{2}$ and mineralogical composition of the plaster evaluated based on the chemical analysis. On careful observation, it is noticed that plasters of earlier period were generally of coarse texture as compared to finer texture observed in the later period plaster. Many samples from Golconda, Charminar and Hampi etc were analysed but for comparative analytical results, a few specified samples have been taken into account.

Surveys of the work carried out in ancient western plasters indicate that so for correlation of composition with period has but been successful. The need was felt to try this phenomenon on Indian plaster works. Chemical composition of various lime plasters along with the period is shown in Table 1. It is observed from the data that lime/silica ratio of the plaster are decreasing from Post Ashokan (200BC) to Charminar (1600AD). The maxima of lime/silica ratio of the plasters, each period shows a very erratic behaviour and plasters are found to be prepared using any desired ratio as per physical requirements. However, the minima of lime/silica ratio of the plaster show gradual decrease from Post Ashokan (1.24) to Charminar (0.44). The minima lime/silica ratio of the plasters belonging to different period is shown in Table 2. It is observed that there is a gradual addition of sand to lime in the later periods as in modern time we keep lime/silica ratio of 0.33 for best quality plaster. Studies show that there is a wide variation in the lime/silica ratio of the plasters applied on different locations of the same monument. Importance of the place, differences in the composition of raw materials used in the process etc. have played important part for these variations. Besides, the monuments were constructed and plastered at different time resulting wide fluctuations in the chemical composition of plasters applied on different locations of the same monument. Hence, if only the minima of lime /silica ratio of the plaster are considered, these can be correlated with its durability, strength and technological evolution. However, for such correlation analysis of large number of samples must be undertaken to get the desired results. 


\begin{tabular}{llllllllllll} 
Sr. no & $\mathrm{SiO}_{2}$ & $\mathrm{Fe}_{2} \mathrm{O}_{3}$ & $\mathrm{Al}_{2} \mathrm{O}_{3}$ & $\mathrm{TiO}_{2}$ & $\mathrm{CaO}$ & $\mathrm{MgO}$ & $\mathrm{Na}_{2} \mathrm{O}$ & $\mathrm{K}_{2} \mathrm{O}$ & $\mathrm{MnO}$ & $\mathrm{LOI}$ & $\mathrm{CaO}_{\mathbf{S i O}}$ \\
\hline $\mathrm{I}$ & 41.8 & 5.96 & 1.73 & 0.11 & 24 & 0.75 & 1.04 & 2.35 & 0.05 & 19.5 & 0.57 \\
2 & 46.5 & 5.35 & 1.56 & 0.15 & 23.4 & 1.2 & 0.5 & 1.15 & 0.03 & 19.5 & 0.5 \\
3 & 44.8 & 3.68 & 1.82 & 0.19 & 24.7 & 1.12 & 0.86 & 1.25 & 0.04 & 20.8 & 0.55 \\
4 & 38.4 & 2.76 & 0.67 & 0.07 & 28.9 & 0.53 & 0.96 & 0.65 & 0.02 & 22.1 & 0.75 \\
5 & 46.3 & 4.36 & 1.66 & 0.24 & 23.1 & 1.46 & 0.71 & 2.52 & 0.03 & 18.9 & 0.5 \\
6 & 49.5 & 1.66 & 6.35 & 0.15 & 22 & 1.19 & - & - & - & 18.8 & 0.44 \\
\hline
\end{tabular}

Hampi (1336-I570 AD)

\begin{tabular}{llllllllllll}
\hline Sr. no & $\mathrm{SiO}_{2}$ & $\mathrm{Fe}_{2} \mathrm{O}_{3}$ & $\mathrm{Al}_{2} \mathrm{O}_{3}$ & $\mathrm{TiO}_{2}$ & $\mathrm{CaO}$ & $\mathrm{MgO}$ & $\mathrm{Na}_{2} \mathrm{O}$ & $\mathrm{K}_{2} \mathrm{O}$ & $\mathrm{MnO}$ & $\mathrm{LOI}$ & $\mathrm{CaO} / \mathrm{SiO}$ \\
\hline $\mathrm{I}$ & 34.46 & 2 & 6.77 & - & $27.6 \mathrm{I}$ & 0.37 & 2.05 & 2.9 & - & 22.6 & $0.080 \mathrm{I}$ \\
2 & 65.3 & 1.56 & 9.71 & - & 8.6 & 0.63 & 4.18 & 5 & - & 7.1 & 0.13 \\
3 & 21.95 & 1.74 & 4.23 & - & 34.9 & 1.88 & 1.59 & 1.7 & - & 30.2 & 1.59 \\
4 & 18.6 & 1.4 & 3.77 & - & 37.78 & 2.03 & 1.12 & $\mathrm{I} .1$ & - & 32.5 & 2.03 \\
\hline
\end{tabular}

Bidar Fort (I400-I600 AD)

\begin{tabular}{llllllllllll}
\hline Sr.no & $\mathrm{SiO}_{2}$ & $\mathrm{Fe2O}_{3}$ & $\mathrm{Al}_{2} \mathrm{O}_{3}$ & $\mathrm{TiO}_{2}$ & $\mathrm{CaO}$ & $\mathrm{MgO}$ & $\mathrm{Na}_{2} \mathrm{O}$ & $\mathrm{K}_{2} \mathrm{O}$ & $\mathrm{MnO}$ & $\mathrm{LOI}$ & $\mathrm{CaO} / \mathrm{SiO}$ \\
\hline $\mathrm{I}$ & 15.85 & 6.87 & 4.7 & 0.71 & 36 & 1.77 & 0.59 & 0.54 & 0.1 & 33.25 & 2.27 \\
2 & 17.05 & 7.01 & 6.05 & 0.75 & 33.6 & 2.89 & 0.36 & 0.61 & 0.11 & 30.09 & 1.97 \\
3 & 15.17 & 8.59 & 4.19 & 0.79 & 35.6 & 1.39 & 0.21 & 0.28 & 0.1 & 31.86 & 2.39 \\
\hline
\end{tabular}

Table 2 Lime/Silica ratio of different period

\begin{tabular}{lll}
\hline Sr. no & Period & Variation in lime/Silica ratio \\
\hline I & Post Ashokan (200 BC) & $1.24-2.33$ \\
2 & Greek \& Roman & $0.62-3.5$ I \\
3 & Satavahana (200 AD) & $0.76-2.69$ \\
4 & Ikshvaku(300AD) & $0.67-3.57$ \\
5 & Alampur(600-700 AD) & $0.57-0.64$ \\
6 & Bidar Fort (I400-I600 AD) & $1.97-2.39 *$ \\
7 & Golconda Fort(I5I8-I687 AD) & $0.57-8.67$ \\
8 & Charminar(I59I-I593AD) & $0.44-0.75$ \\
9 & Modern & 0.33 \\
\hline
\end{tabular}

*Only three samples were available for analysis

Besides, some of Indian monuments were found prepared with dolomitic lime stone, one such example is kudali Sangmeshwara temple at Alampur (6-7 Century AD) about $150 \mathrm{~km}$ from Hyderabad at the confluence of Krishna and Tungabhadra river, constructed by Chalukya's of Badami . The chemical \& mineralogical composition of plaster samples taken from five different locations of the monument from the sheltered portion is shown in Table 3. From the mineralogical composition of the plasters, it is observed that magnesium carbonate content is quite low $(<2.5 \%)$ in the most of the other plasterworks whereas it varies from $5.35 \%$ to $8.10 \%$ in the plaster works of Alampur. This high proportion of magnesium mineral in the plasters can never be an impurity from carboniferous lime stone, generally used in the preparation of plasters containing very little or no magnesium. Since magnesium carbonate is very prone to damage if it gets wet, it is essential to take extra precautions to check seepage of water wherever dolomitic plasterworks are present in our monuments. As the plasters have been prepared using locally available raw materials and source of dolomitic lime stone is reported in Kurnool, about $25 \mathrm{Km}$ from Alampur there is a possibility of using dolomitic lime stone from that source for Alampur plaster works.

Second important aspect of lime work of Alampur is the degree of hydraulicity of dolomitic plaster. Hydraulic components are those components of plasters which set without air and mostly consist of di-calcium silicate and di-calcium aluminate. It comes into the plasterworks either by deliberate addition or by firing lime stone having clay impurity up to a temperature of $1100^{\circ} \mathrm{c}$. Hydraulic component gives strength to the plaster and also makes it to set rapidly. To give hydraulicity to the plaster, addition of fine bricks dust, powdered tiles, pozzolana, fumed silica etc. are made into the lime since they contain active silica $\&$ alumina. From the mineralogical composition of Charminar, ${ }^{1}$ Bidar Fort ${ }^{3}$ \& Hampi plaster works, it is observed that hydraulic component determined are 1.44 to $8.8 \%, 5.33$ to $7.54 \%$ and 0.34 to $2.9 \%$,respectively. These may be either impurities from the lime stone or little quantity of deliberate addition to enhance setting properties of the plaster. However, hydraulic components determined in the plasterworks of Alampur are between 12 to $25 \%$, a very deliberate addition. It seems that lime technicians at Alampur were familiar with the weaknesses of dolomitic lime and hence added higher quantity of hydraulic components to enhance strength and setting properties of the plaster. The survival of plasterworks of Alampur can therefore be correlated with this factor. From the mineralogical data it is also observed that higher amount of hydraulic component were added in those plasterworks which were found having less amount of sand at Alampur to compensate for its durability and strength.

Another interesting feature observed was in the lime works of Lotus Mahal, Hampi (Figure 1). Situated on the bank of river Tungabhadra, Hampi is famous for its group of monuments under world Heritage List belonging to the period 1336-1570 AD with beautiful plasterworks. 
For investigative purpose four samples from different location of the lotus mahal were analysed. From the chemical composition of Hampi plaster (Table 1) and based on the Mgo/Cao ratio of plasters, it is observed that the nature of lime throughout the construction at Hampi did not remain the same and at some places partially dolomitic lime seems to have been used. The mineralogical compositions of Hampi plaster is shown in Table-4. From the variation of hydraulic component it is observed that the lime used in the preparation of plaster was very partially hydraulic. The mineralogical composition of calcite show that the lime used may not be of same origin since the monument was built at different period. Sample $3 \& 4$ indicate that partially dolomitic lime source quite different to earlier one was used at some places in the construction of the monument. From Table 4 it is also observed that percentage of binder is more than percentage of aggregate except in sample No.2. The ratio of binder to inert material also indicates that the quality \& provenance of the material used in the preparation of Hampi plaster may not always be same through the same procedure might have been adopted in the preparation of plaster. This is quite contrary to the studies made on other plaster of medieval period wherein granular behaviour does not depict wide variations in the characteristics \& production technology of the plaster. The main intention of finding the mineralogical composition is to set a standard mixing proportion for the synthesis of new plaster like ancient one for re-plastering for aesthetic and aging purpose.

Table 3 Percentage Chemical and Mineralogical composition of Alampur plasterworks

\begin{tabular}{lllllllll}
\hline Sr. no & $\mathbf{C a O}$ & $\mathbf{M g O}$ & $\mathbf{R}_{2} \mathbf{O}_{3}$ & Insoluble matter (Mostly Silica) & Moisture & LOI & $\mathrm{CaO} / S i O_{2}$ \\
\hline I & 28.24 & 2.55 & 6.38 & 49.22 & 1.66 & 10.23 & 0.57 \\
2 & 28.55 & 4.09 & 4.23 & 44.42 & 4.96 & 12.14 & 0.64 \\
3 & 29.92 & 3.86 & 2.36 & 49.02 & 0.59 & 15.56 & 0.61 \\
4 & 27 & 2.23 & 2.72 & 48.5 & 5.56 & 12.56 & 0.56 \\
5 & 29.6 & 3.88 & 3 & 51.32 & 0.26 & 10.82 & 0.57 \\
\hline
\end{tabular}

Percentage Mineralogical composition of Alampur plaster works*

\begin{tabular}{lllllll}
\hline Sr. no & $\mathrm{CaCO}_{3}$ & $\mathrm{MgCO}_{3}$ & Quartz & Non-hydrolic & Hydrolic & Mgo/Cao \\
\hline I & 16.87 & 5.35 & 31.09 & 24.51 & 11.75 & 0.09 \\
2 & 17.55 & 8.42 & 15.47 & 33.2 & 24.69 & 0.14 \\
3 & 25.71 & 8.1 & 33.91 & 17.47 & 12.75 & 0.13 \\
4 & 22.97 & 4.68 & 24.65 & 26.59 & 21.13 & 0.08 \\
5 & 14.89 & 6.3 & 36.39 & 17.93 & 11.93 & 0.13 \\
\hline
\end{tabular}

*This does not include organic matter and other soluble salts

Table 4 Percentage Mineralogical composition of Hampi plasters*

\begin{tabular}{llllllll}
\hline Sr. NO & $\mathrm{CaCO}_{3}$ & $\mathrm{MgCO}_{3}$ & Quartz & Non-hydraulic & Hydraulic & Acid soluble & Aggregate \\
\hline 1 & 48.12 & 0.77 & 19.4 & 28.78 & 1.34 & 51.22 & 48.12 \\
2 & 13.9 & 1.32 & 44.51 & 44.51 & 0.34 & 16.52 & 85.75 \\
3 & 50.55 & 3.95 & 10.59 & 10.69 & 2 & 66.63 & 31.21 \\
4 & 64.88 & 4.26 & 8.75 & 8.75 & 2.9 & 72.73 & 25.55 \\
\hline
\end{tabular}

*Percentage excludes organic matter \& other soluble salts

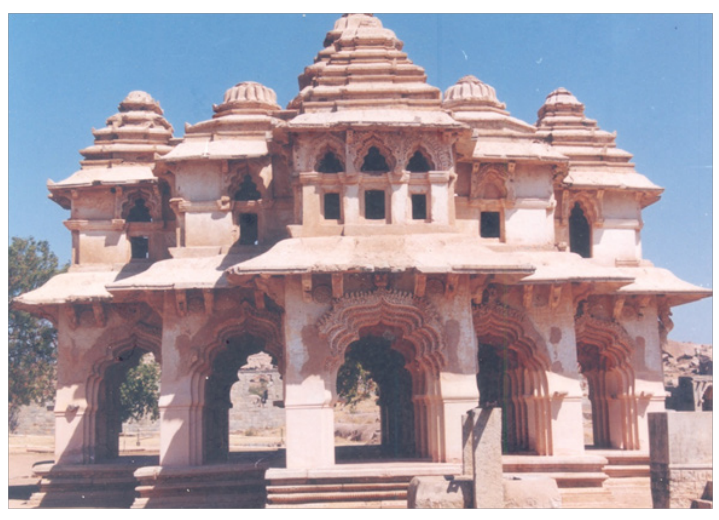

Figure I General View of Lotus Mahal Hampi.

\section{Conclusion}

From the physical verification of nature of plasters of different period in India, it is observed that its strength and survival are in consonance to its chemical/mineralogical findings. Due to dolomitic nature of materials used, the weak plasters are noticed at Alampur where loss because wetting has been noticed. At Lotus Mahal, Hampi the weak plasters are noticed in Queen's bath \& store room where slightly dolomitic lime has been introduced in plasterworks in accordance with the scientific findings. At Golconda, the plasters have peeled off from those parts of the fort where less silica \& more addition of organic matters have been made in the plaster such as main door, outer periphery wall etc. whereas the plasters of Kings/Queen palaces, Rangeen Mahal etc. are still intact and is good state of preservation. Due to uniformity in nature and better methodology adopted in its 
preparation, the plasterworks of Charminar is probably the best surviving and shows greater durability/strength and technological evolution in accordance with its chemical/mineralogical findings.

\section{Acknowledgements}

The author is thankful to Dr. B.R. Mani, Vice chancellor, National Museum Institute, New Delhi for his interest and support for this research work.

\section{Conflict of interest}

Author declares there is no conflict of interest in publishing the article.

\section{References}

1. Singh M. Analysis and characterization of Charminar lime plaster. Current science. 1993;64(10):760-764.

2. Singh M. Studies on Lime plasters of Golconda Fort. Proceeding of Ist International Colloquium on Role of Chemistry in Archaeology. Birla Institute of Scientific Research, India; 1991. p. $81-86$.

3. Singh M, Sharma RK. Chemical characterization of Bidar Fort (India) plaster. International Seminar on Conservation, Preservation \& Restoration-Traditions, Trends \& Techniques, Birla Archaeological and Cultural Research Institute, India; 1995. p. 103-110.
4. Aslam M. Studies on Taj Mahal Plasters. Studies in conservation. 1990;35(2):102-106.

5. Cooper AD. Building Research Special Report No. 9. 1927.

6. Profi S, Weier L, Fillippakis JE. Studies in Conservation. 1974;19(2):105-112.

7. Torraca G. Porous Building Materials Science for Architectural Conservation. 3rd edition. ICCROM, Rome; 1988.

8. Stafford H, Wingate M. Building with lime: A practical Introduction. Intermediate Technology Publications, India; 1997. p. 309.

9. Beard G. Decorative Plasterworks of Great Britain. Phaiden Press, London, UK; 1975. p. 262.

10. Singh M, Arbad BR. Characterization of $4-5^{\text {th }}$ century A.D. earthen plaster support layers of Ajanta Mural paintings. Construction and Building materials. 2015;82:142-154.

11. Newton RG, Sharp JH. An investigation of the chemical constituents of some renaissance plasters. Studies in Conservation. 1987;32(4):163-175.

12. Rao NR, Prasad KM. Studies on some lime plasters. $J$ Archaeological Chemistry. 1985;3:13-19. 